\title{
In vitro antifungal activity of endophytic bacteria isolated from date palm (Phoenix doctylifera L.) against fungal pathogens causing leaf spot of date palm
}

\author{
H. H. Al-Nadabi* (D, N. S. Al-Buraiki, A. A. Al-Nabhani, S. N. Maharachchikumbura, R. Velazhahan and A. M. Al-Sadi
}

\begin{abstract}
Background: Date palm ((Phoenix doctylifera L.) suffers from several fungal diseases. The endophytic microorganisms present in higher plants generally offer protection to their host plants against invading phytopathogenic fungi and bacteria. In the present study, endophytic bacteria associated with date palm leaves were isolated and their in vitro antagonistic potential against fungal pathogens causing leaf spots in date palm was demonstrated.

Results: Endophytic bacteria were isolated from date palm leaves of 3 different cultivars viz., Nighal, Khalas and Khinaizi and evaluated for their inhibitory activity against leaf spot pathogens of date palm viz., Fusarium solani, Alternaria sp., Nigrospora sp., Thieloviopsis sp., Curvularia subpapendrofii and Tilletiopsis minor using an in vitro dual culture assay. Of the 24 endophytic bacterial strains tested, the endophytes designated B1, B7, B8 and B9 obtained from cv. Nighal showed inhibitory activities (more than 55\% mycelial growth inhibition) against F. solani and Alternaria sp. None of the bacterial endophytes inhibited the growth of other fungal pathogens tested. These antagonistic bacterial strains were identified as Pantoea septica on the basis of $16 \mathrm{~S}$ rRNA gene sequence analysis. The hyphae of F. solani and Alternaria sp. exhibited morphological abnormalities such as shrinkage and disintegration when grown in the presence of antagonistic bacterial endophytes. The cell-free culture filtrates of the bacterial endophytes caused inhibition of mycelial growth and induced leakage of electrolytes from the mycelia of F. solani and Alternaria sp. This is the first study that describes inhibition of the date palm pathogens $F$. solani and Alternaria sp. by P. septica.

Conclusion: Endophytic Pantoea septica strains isolated from date palm leaves inhibited the mycelial growth of $F$. solani and Alternaria sp. and induced morphological changes in their mycelia. The culture filtrates of these bacterial strains also inhibited the mycelial growth and caused leakage of electrolytes from the mycelia of $F$. solani and Alternaria sp. These promising bacterial strains can be exploited as biocontrol agents to control $F$. solani and Alternaria sp.-induced leaf spot diseases of date palm.
\end{abstract}

Keywords: Alternaria sp., Antifungal, Endophytic bacteria, Foliar pathogens, Fusarium solani, Phoenix doctylifera

\footnotetext{
* Correspondence: hamed@squ.edu.om

Department of Crop Sciences, College of Agricultural and Marine Sciences, Sultan Qaboos University, PO Box 34, Alkhoud, 123 Muscat, Oman
}

(C) The Author(s). 2021 Open Access This article is licensed under a Creative Commons Attribution 4.0 International License, which permits use, sharing, adaptation, distribution and reproduction in any medium or format, as long as you give appropriate credit to the original author(s) and the source, provide a link to the Creative Commons licence, and indicate if changes were made. The images or other third party material in this article are included in the article's Creative Commons licence, unless indicated otherwise in a credit line to the material. If material is not included in the article's Creative Commons licence and your intended use is not permitted by statutory regulation or exceeds the permitted use, you will need to obtain permission directly from the copyright holder. To view a copy of this licence, visit http://creativecommons.org/licenses/by/4.0/. 


\section{Background}

Date palm (Phoenix doctylifera L.) is the principal economic crop in Oman with a total yield of 360,917 tons annually, which makes Oman amongst the top 10 producers of dates globally (FAO 2019). The major constraints for date's production in Oman are drought, salinity, pests and diseases. Date palms are affected by many foliar, root and fruit diseases. The most serious disease of date palm in the world is Bayoud disease induced by the fungus Fusarium oxysporum f. sp. albedinis (Chao and Krueger 2007). Although it is limited in distribution to some areas, mostly in Morocco and Algeria, it resulted in the destruction of two-thirds of palm trees (El Hassni et al. 2007). Wilt, leaf spots, black scorch, root rots and fruit rots are the other most commonly found diseases in date palms. Leaf spot diseases cause lower economic losses compared to other diseases (AlNadabi et al. 2018). Many fungi are reported and proven to cause leaf spot diseases in date palms such as: Alternaria, Mycosphaerella, Chaetosphaeropsis, Phoma and Phomopsis (El-Deeb et al. 2007). In Oman, Alternaria alternata, A. burnsii, A. arborescens, A. jacinthicola, A. tomato and $A$. slovaca are the major fungal pathogens of leaf spot disease of date palm (Al-Nadabi et al. 2018). Despite these challenges, date palms withstand and show adaptations features.

Endophytic microbial communities contribute significantly to the growth of the plants under regular and stress status. Endophytic bacteria are known for their colonization ability in inner plant tissues without leading to any disease (Yaish et al. 2016). Many endophytic bacteria have been proved to have antimicrobial activities and many of them have been utilized against plant diseases (Mohamad et al. 2018). Over the last twenty years, biological control has become an important alternative to control pests and diseases that affect plants, especially with the emergence of pest resistance to chemical pesticides and for the protection of the environment and to ensure sustainable agriculture (Huffaker 2012). Biocontrol agents control diseases by direct and/or an indirect interaction with the causal agents (Pal and Gardener 2006). The direct impact is mostly due to the antagonism of the biocontrol agent toward the pathogen resulting from nutrient competition or antibiosis and/or parasitism, while the indirect effect is due to stimulation of plant defence mechanisms against various pests and diseases (Heydari and Pessarakli 2010). Previous studies have attempted with Streptomyces globosus and Trichoderma harzianum for controlling black scorch disease in date palm (Saeed et al. 2017). Moreover, there are several studies on the uses of microorganisms such as $B a$ cillus amyloliquefaciens and Burkholderia cepacia as biocontrol agents for controlling bayoud disease in date palm (El Hassni et al. 2007). To our knowledge, there are no previous studies on the use of endophytic microorganisms for controlling foliar diseases of date palms.

In this research, endophytic bacteria were isolated from date palm leaves and their antagonistic potential against fungal pathogens causing leaf spots of date palm was demonstrated.

\section{Methods \\ Isolation of endophytic bacteria}

Twelve leaf samples were gathered from 3 date palm cultivars viz., Khalas, Nighal and Khinaizi (four samples from each location) at 3 different locations (GPS coordinates 23.232825,58.078146; 23.233959,58.082256; 23.233851,58.082413) in the village of Al-Fankh, Samael, Oman. Samples were collected in sterile paper bags and processed on the same day of collection. Leaves were ruptured into pieces and sterilized with 5\% sodium hypochlorite for $3 \mathrm{~min}$, followed by washing in distilled water for 3 times and dried by filter paper. The chopped leaves were then crushed in a sterile mortar and the sap was streaked on nutrient agar (NA) plate. The sterile water obtained from the last washing step was streaked on NA plate as a control. Followed by the incubation of the plates at $27^{\circ} \mathrm{C}$ for 3 days. The selection of bacterial colonies was based on distinct morphological features (colour, size, shape) and pure cultures were obtained by streak-plate technique (Al-Hussini et al. 2019).

\section{Fungal pathogens}

The isolates of different pathogenic fungi viz., Fusarium solani 2114, Curvularia subpendrofi 2315, Tilletiopsis minor 2110, T. minor 2111, Alternaria sp. 2372, Nigrospora sp. 2394 and Thieloviopsis sp. 2107, used in this work, came from the previous collections of Al-Nadabi et al. (2020). These fungal pathogens were isolated from date palm leaves infected with leaf spot disease collected from different governorates of Oman. All of them were cultured on PDA medium at $25 \pm 2{ }^{\circ} \mathrm{C}$.

\section{In vitro testing for antagonistic activity}

Twenty-four bacterial strains (13 strains from Nighal, 6 from Khinaizi and 5 from Khalas) were investigated in vitro for their antagonistic vitality against 7 foliar fungal pathogens of date palm by dual culture technique. A bacterial colony was streaked at one end of a 9-cm Petri dish containing NA medium. A 7-mm mycelial disc of a 7-day-old culture of the test fungal pathogens was placed on the other end and incubated at $27^{\circ} \mathrm{C}$ until mycelial growth of the test fungus covers the entire Petri plate in the control. In the control plate, only a fungal disc was placed. At the end, the inhibition zone was measured by counting the distance between the 2 sides of the tested Petri dish (Al-Hussini et al. 2019). 


\section{Molecular characterizations DNA extraction}

The DNA of the bacterial strains was extracted using a foodproof StarPrep Two kit (BIOTECON Diagnostics, Germany). The quality and concentrations of DNA were measured by the NanoDrop 1000 Spectrophotometer (Thermo Scientific, USA) in accordance with the manufacturer's direction.

\section{PCR amplification and sequencing}

The identification of endophytic bacterial isolates was achieved by PCR amplification of 16S rRNA genes with universal primers viz., 27F (5'AGAGTTTGATCMTGGCTCAG-3'), 1429R (5'-TACGGYTACC

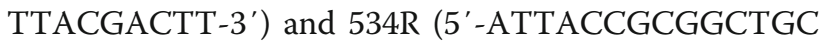
TGG-3') (Al-Hussini et al. 2019). PCR was carried out with $25 \mu \mathrm{l}$ of PCR reaction mixture containing PuRe Ready-to-go PCR beads (GE Healthcare), $22 \mu \mathrm{l}$ of sterile distilled water, $1 \mu \mathrm{l}$ of each primer and $1 \mu \mathrm{l}$ of DNA. PCR conditions included of initial DNA denaturation at $95^{\circ} \mathrm{C}$ for $2 \mathrm{~min}$, followed by 35 cycles of $30 \mathrm{~s}$ at $95^{\circ} \mathrm{C}$, $30 \mathrm{~s}$ at $54^{\circ} \mathrm{C}, 1 \mathrm{~min}$ at $72{ }^{\circ} \mathrm{C}$ and a final extension at $72^{\circ} \mathrm{C}$ for $10 \mathrm{~min}$. Finally, PCR products were sent to Korea for purification and sequencing at Macrogen Inc.

\section{Phylogenetic analysis}

The software MEGA v.7.0.26 was used for generating the multiple sequence alignments. Maximum likelihood (ML) was analysed through RAxMLGUI v. 1.3 (Silvestro and Michalak 2012). The search of optimal ML tree was performed with 1000 separate runs from a random starting tree for each run using the default algorithm of the program. Based on suboptimal trees from each run, the final trees were selected by comparing likelihood scores under the GTR+GAMMA substitution model evolution by MrModeltest 2.2. The software MEGA v.7.0.26 was used for printing the generated tree, while Adobe Illustrator CS v.6 was employed for making the layout.

\section{Morphological changes in the fungal pathogens due to antagonistic effects of endophytic bacterial strains}

Scanning electron microscopy (SEM) was used to study the morphological changes of susceptible fungal species (F. solani and Alternaria sp.) due to antagonistic activity of bacterial endophytes. A small piece of fungal mycelia taken from the inhibition zone in the dual culture plate was transferred into a glass vial containing fixative buffer (2.0 g paraformaldehyde, $8.0 \mathrm{ml}$ of $25 \%$ glutaraldehyde, 1 $\mathrm{N} \mathrm{NaOH}, 1 \mathrm{~N} \mathrm{HCl}, 10 \mathrm{ml}$ of $0.1 \mathrm{ml}$ sodium cacodylate, $2.0 \mathrm{~g}$ of sucrose, $1.0 \mathrm{ml}$ of $1 \% \mathrm{CaCl}_{2}, 1.01 \% \mathrm{MgCl}_{2}$ and $100 \mathrm{ml}$ of distilled water) and incubated at $36^{\circ} \mathrm{C}$. On the next day, buffer was removed and sufficient quantity of the osmium tetroxide was added and mixed in a rotor for one hour. The previous step was repeated by using distilled water twice and kept in the rotor for $10 \mathrm{~min}$, followed by washing with absolute ethanol four times for $10 \mathrm{~min}, 10 \mathrm{~min}, 20 \mathrm{~min}$ and $10 \mathrm{~min}$. Then the samples were kept overnight and dried. Finally, samples were coated with platinum and observed using a JEOL scanning electron microscope model JSM-7800F (JEOL, MA, USA).

\section{Evaluation of cell-free culture filtrates of endophytic bacteria for antifungal activity}

The evaluation of antifungal activity of cell-free culture supernatants from bacterial strains B1, B7, B8 and B9 against $F$. solani and Alternaria sp. was achieved by poisoned food technique as described by Kumar et al. (2008). Antagonistic bacterial strains were cultured in nutrient broth for $48 \mathrm{~h}$ at $28^{\circ} \mathrm{C}$ on an incubator shaker (150 rpm). Followed by centrifugation of bacterial culture for $10 \mathrm{~min}$ at $12,000 \mathrm{rpm}$ at temperature of $4{ }^{\circ} \mathrm{C}$ and the supernatant was collected. After that, the bacterial culture supernatant was filtered by a $0.2 \mu \mathrm{m}$ sterilized syringe filter. PDA plates amended with different concentrations (2.5, 5.0, 7.5 and 10\%) of cell-free culture supernatants were prepared. Then, 6-mm diameter of a mycelial disc cut out from 7-day-old culture and placed on the centre of agar medium. Next, incubated at $25^{\circ} \mathrm{C}$ and the mycelial growth was measured after 7 days. The percentage of inhibition of mycelial growth was calculated, using the following formula (Pandey et al. 1982)

$$
\text { Percentage of mycelial inhibition }=\frac{D c-d t}{D c} \times 100
$$

where $D c$ average diameter of fungal colony in control and $d t=$ average diameter of fungal colony in treatment.

\section{Testing antifungal metabolites production by bacterial endophytes}

The antifungal metabolites production by endophytic bacterial strains was evaluated using electrolyte leakage bioassay (Manhas and Kaur 2016). The supernatants of cell-free culture of the endophytic bacterial strains were prepared as described above. Then, $0.5 \mathrm{~g}$ of fungal mycelium (F. solani and Alternaria sp.) was added to $10 \mathrm{ml}$ of cell-free bacterial culture supernatant in glass vials. Finally, the samples were placed at room temperature $\left(25 \pm 2^{\circ} \mathrm{C}\right)$ and then the conductivity of the mixture was assayed at 0 and $2 \mathrm{~h}$ by using the conductivity meter (Prapagdee et al. 2008).

\section{Statistical analysis}

Data were analysed using PSPPIRE (PSPP+GUI). Treatment means $\pm \mathrm{SD}$ were compared using one-way ANOVA and Tukey test. 


\section{Results}

Isolation and in vitro screening of endophytic bacteria Twenty-four endophytic bacterial strains (B1-B24), with distinguished colony morphologies, were isolated from the leaves of date palm collected from Nighal (B1-B13), Khinaizi (B14-B19) and Khalas (B20-B24) cultivars. The antagonistic activities of the bacterial strains were tested against F. solani, Alternaria sp., Nigrospora sp., Thieloviopsis sp., C. subpapendrofii, T. minor and Tilletiopsis sp. in vitro by using a dual culture technique. Out of tested strains, the endophytic bacteria isolated from date palm cultivar Nighal alone showed inhibitory activity against the fungal pathogens tested. Of the 13 bacterial strains (B1-B13) from the date palm cv. Nighal, except $B 10$, all the other strains inhibited the mycelial growth of F. solani. Four bacterial strains (B1, B7, B8 and B9) were found to be effective in restricting the mycelial growth of Alternaria sp. (Table 1). None of the bacterial strains tested was found effective against Nigrospora sp., Thieloviopsis sp., C. subpapendrofii, T. minor and Tilletiopsis sp.

\section{Molecular characterization of bacterial endophytes}

The 4 bacterial strains (B1, B7, B8 and B9), which exhibited antagonistic potential against both $F$. solani and Alternaria sp., were identified by $16 \mathrm{~S}$ rRNA gene sequencing. Based on the phylogenetic analysis, all the 4 strains were identified as Pantoea septica (Fig. 1). The nucleotide sequences of 4 bacterial strains (B1, B7, B8 and B9) were deposited in GenBank with accession numbers MT355663, MT355662, MT355664 and MT355665, respectively.

\section{SEM observation}

Examination of the hyphae of $F$. solani and Alternaria sp. from the dual culture assay plate by SEM revealed morphological alterations. Shrinkage and distortion of $F$. solani hyphae were observed when the fungus was cocultivated with the $P$. septica strain B1. The hyphae of $F$. solani exhibited loss of turgidity, shrinkage and fragmentation when exposed to P. septica strains B7, B8 and B9.

Table 1 In vitro antagonistic activity of endophytic bacterial isolates against Fusarium solani and Alternaria sp.

\begin{tabular}{lll}
\hline $\begin{array}{l}\text { Endophytic } \\
\text { bacterial } \\
\text { strains }\end{array}$ & \multicolumn{2}{l}{$\%$ inhibition of mycelial growth } \\
\cline { 2 - 3 } & Fusarium solani & Alternaria sp. \\
\hline B1 & $65.88 \pm 0.1 \mathrm{C}$ & $55.54 \pm 0.48 \mathrm{c}$ \\
B7 & $61.18 \pm 0.39 \mathrm{~d}$ & $58.63 \pm 0.34 \mathrm{~b}$ \\
B8 & $71.76 \pm 0.42 \mathrm{~b}$ & $58.14 \pm 0.26 \mathrm{~b}$ \\
B9 & $75.31 \pm 0.67 \mathrm{a}$ & $65.14 \pm 0.27 \mathrm{a}$ \\
\hline
\end{tabular}

Data are mean of three replications $( \pm S D)$

Values of the same letter have no significant differences from each other at $P<0.05$
The control hyphae were healthy, normal in growth with smooth surface (Fig. 2). The hyphae of Alternaria sp. also exhibited shrinkage and disintegration when treated with the bacterial endophytes (Fig. 2).

\section{Antifungal activity of cell-free culture supernatants of endophytic bacteria}

The test of a poisoned food technique showed that the cell-free culture supernatants of $P$. septica strains B1, B7, B8 and B9 exhibited inhibitory activities against $F$. solani and Alternaria sp. The culture supernatants of all the 4 bacterial endophytes caused $100 \%$ inhibition of the mycelial growth of $F$. solani and Alternaria sp. at all the 4 concentrations tested (Table 2). The culture supernatants of P. septica strain B1 completely inhibited the mycelial growth of Alternaria sp. at all the 4 concentrations tested, whereas the other 3 strains of $P$. septica showed varying levels of inhibitory activities (Fig. 3).

\section{Production of antifungal metabolites by antagonists}

The electrolyte leakage assay was used for testing the production of antifungal metabolites by $P$. septica strains. The culture supernatants of all the $4 P$. septica strains caused damage and leakage from mycelium cellular electrolytes of $F$. solani and Alternaria sp. as proved by raised levels of electrical conductivity (Table 3 ). Amongst them, P. septica strain B9 induced the highest of electrolytes release from the mycelia of $F$. solani and Alternaria sp. (Table 3).

\section{Discussion}

Endophytic microorganisms are distributed in a wide range of host plants including vegetable crops, ornamental plants, grasses, medicinal plants and tree crops (Rosenblueth and Martínez-Romero 2006). The involvement of endophytes in plant disease control, induction of resistance in plants against biotic and abiotic stresses, plant growth promotion, production of novel bioactive compounds and detoxification of toxic compounds has been well documented (Al-Badri et al. 2020). Endophytic fungi (Ben Mefteh et al. 2018) and bacteria (Yaish et al. 2015) have been isolated and characterized from date palm roots. Ben Mefteh et al. (2018) reported that endophytic fungi viz. Penicillium citrinum and Geotrichum candidum obtained from date palm tree roots showed antifungal and antibacterial activities. El-Deeb and Arab (2013) reported Acremonium spp. as date palm root endophytes. However, limited information is available in the literature regarding endophytes of date palm leaves (Siala et al. 2016) who isolated endophytic bacterial strains belonging to Enterobacteriaceae, Microbacteriaceae and Pseudomonadaceae from date palm leaves and demonstrated that Arthrobacter agilis and Bacillus subtilis showed antagonistic activities against several 


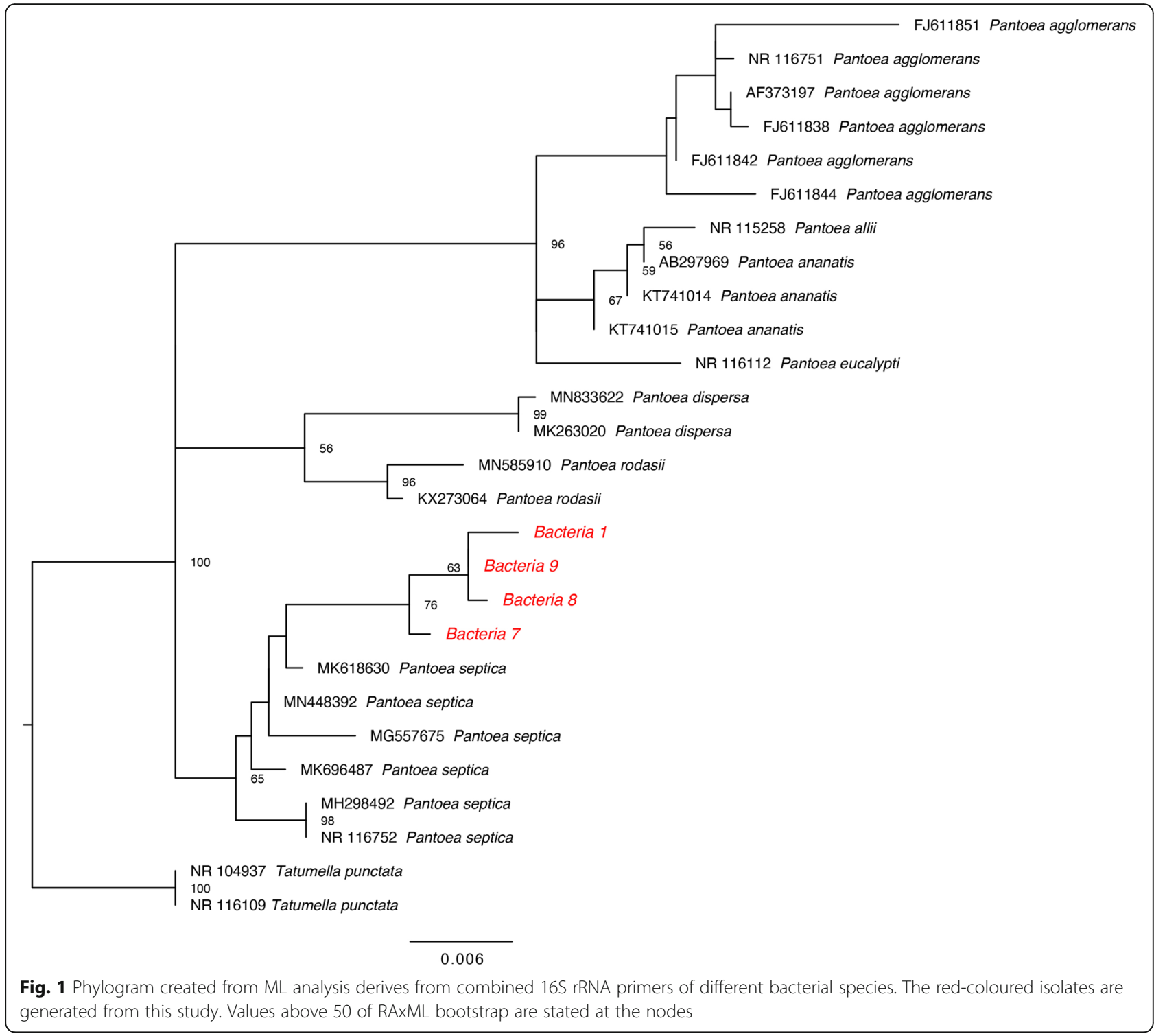

Fusarium species including Fusarium oxysporum f. sp. albedinis, the causal agent of Bayoud disease of date palm. In the present study, endophytic bacteria were isolated from the leaves of 3 different date palm cultivars. These endophytic bacteria might have entered into the roots of date palm through wounds caused by mechanical damage or herbivores and migrated to leaves through transpiration system (Compant et al. 2010) or entered into leaves via stomata (Frank et al. 2017).

In vitro evaluation of the bacterial endophytes for antifungal activity in this research revealed that the bacterial strains obtained from the date palm cultivar Nighal alone exhibited antifungal activity. Four endophytic bacterial strains (B1, B7, B8 and B9) showed inhibitory activity against both $F$. solani and Alternaria sp. On the basis of sequence analysis of $16 \mathrm{~S}$ rRNA gene, all the 4 strains were identified as Pantoea septica. Pantoea species, belonging to the family Enterobacteriaceae, have been isolated from soil and plants (Han-Jen et al. 2013). Pantoea spp. such as $P$. agglomerans, $P$. vagans and $P$. dispersa are widely used as biocontrol agents for controlling fungal and bacterial diseases of plants (Jiang et al. 2019). The antagonistic potential of $P$. agglomerans against Fusarium culmorum, Puccinia recondita f. sp. tritici (Kempf and Wolf 1989), Botrytis cinerea, Penicillium expansum (Bryk et al. 1998), Penicillium digitatum (Plaza et al. 2004) and Macrophomina phaseolina (Vasebi et al. 2015) has been reported. The commercial formulation of $P$. agglomerans strain C9-1 (Nufarm Americas, Burr Ridge, IL) is available for the control of fire blight of apple caused by Erwinia amylovora (Ishimaru et al. 1988). Jiang et al. (2019) demonstrated the potential of $P$. dispersa for controlling black rot of sweet potato caused by Ceratocytis fimbriata. A few species of 


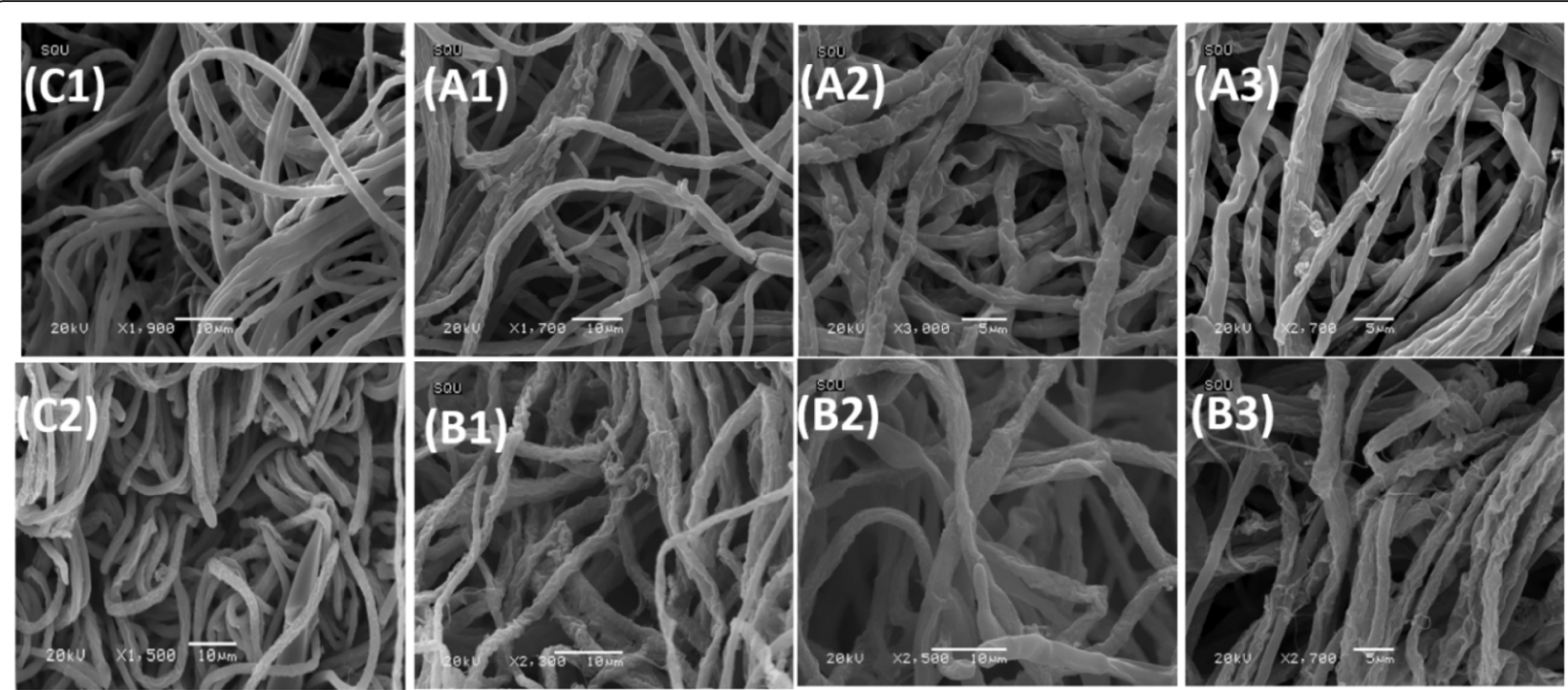

Fig. 2 Scanning electron micrographs showing morphological abnormalities in the hyphae of $F$. solani and Alternaria sp. due to the antagonistic effect of endophytic bacterial strains from date palm (cv. Nighal) ( $C 1$ and $C 2$, control for $F$. solani and Alternaria, respectively; A1-A3, F. solani exposed to B1, B7 and B8; B1-B3, Alternaria sp. exposed to B1, B7 and B8)

Pantoea have been reported to possess plant growthpromoting ability. For instance, Chen et al. (2017) demonstrated that an isolate of $P$. alhagi enhanced the growth of wheat and improved its resistance to drought stress. To our knowledge, this is the first report of antifungal activity of $P$. septica against fungal pathogens of date palm. The endophytic $P$. septica present in the leaves of date palm cv. Nighal might have involved in the resistance of host plants against foliar pathogens. However, the reaction of date palm $c v$. Nighal to foliar fungal pathogens has not been reported so far.

In the present study, the culture supernatants of the endophytic bacterial strains caused inhibition of mycelial growth of $F$. solani and Alternaria sp. Furthermore, the culture supernatants of the antagonistic endophytic bacterial strains caused leakage of cellular electrolytes from the mycelium of $F$. solani and Alternaria sp. suggesting alterations in the permeability of fungal cell membrane (Halo et al. 2018). The leakage of electrolytes from fungal membranes has previously been reported as an indicator of cell membrane damage (Manhas and Kaur 2016; Halo et al. 2018). Many Pantoea spp. are known to produce antimicrobial metabolites (Vasebi et al. 2015). The inhibitory activity of $P$. septica might be due to the production of such diffusible antifungal compounds (Kotze et al. 2011). This was further confirmed by SEM analysis of the fungal hyphae from the inhibition zone, which revealed morphological alterations such as shrinkage, loss of turgidity and distortion of $F$. solani hyphae. The loss of cytoplasmic contents usually results in the shrinkage of hyphae (Garg et al. 2010). The results of the present study suggest the production of antifungal compounds

Table 2 Antifungal activity of cell-free culture supernatants of endophytic bacteria against Fusarium solani and Alternaria sp. as assessed by poisoned food technique

\begin{tabular}{|c|c|c|c|c|c|c|}
\hline \multirow{2}{*}{$\begin{array}{l}\text { Fungal } \\
\text { pathogen }\end{array}$} & \multicolumn{6}{|c|}{ Percent mycelial growth inhibition } \\
\hline & Concentration (\%) & Distilled water control & B1 & B7 & B8 & B9 \\
\hline \multirow[t]{4}{*}{ Fusarium solani } & $2.5 \%$ & $0 \pm 0 \mathrm{~b}$ & $100 \pm 0 a$ & $100 \pm 0 a$ & $100 \pm 0 a$ & $100 \pm 0 a$ \\
\hline & $5 \%$ & $0 \pm 0 b$ & $100 \pm 0 a$ & $100 \pm 0 \mathrm{a}$ & $100 \pm 0 a$ & $100 \pm 0 \mathrm{a}$ \\
\hline & $7.5 \%$ & $0 \pm 0 b$ & $100 \pm 0 a$ & $100 \pm 0 \mathrm{a}$ & $100 \pm 0 a$ & $100 \pm 0 a$ \\
\hline & $10 \%$ & $0 \pm 0 b$ & $100 \pm 0 a$ & $100 \pm 0 \mathrm{a}$ & $100 \pm 0 \mathrm{a}$ & $100 \pm 0 \mathrm{a}$ \\
\hline \multirow[t]{4}{*}{ Alternaria sp. } & $2.5 \%$ & $0 \pm 0 e$ & $100 \pm 0 a$ & $26.7 \pm 0.44 d$ & $56.7 \pm 0.3 b$ & $53 \pm 0.56 c$ \\
\hline & $5 \%$ & $0 \pm 0$ e & $100 \pm 0 a$ & $30 \pm 0.96 c$ & $60 \pm 0.7 b$ & $56.7 \pm 0.6 \mathrm{C}$ \\
\hline & $7.5 \%$ & $0 \pm 0 e$ & $100 \pm 0 a$ & $90 \pm 0.44 c$ & $66.7 \pm 0.56 \mathrm{~d}$ & $70 \pm 0.6 b$ \\
\hline & $10 \%$ & $0 \pm 0 \mathrm{e}$ & $100 \pm 0 a$ & $36.7 \pm 1.4 c$ & $66.37 \pm 0.55 c$ & $73 \pm 0.4 b$ \\
\hline
\end{tabular}




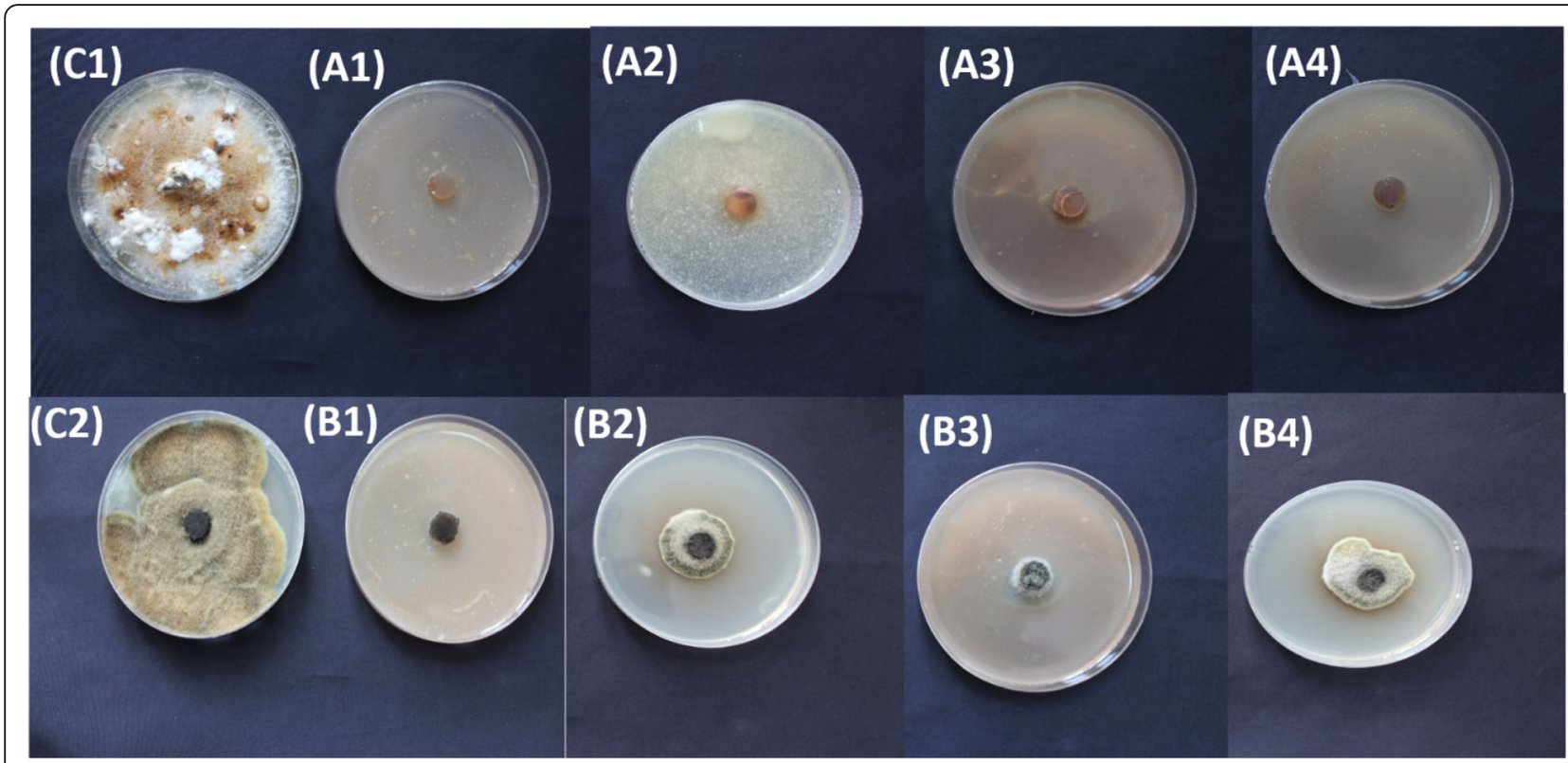

Fig. 3 Inhibition of mycelial growth of F. solani and Alternaria sp. by cell-free culture supernatants of endophytic bacterial strains ( $C 1$ and $C 2$, control for F.solani and Alternaria, respectively; A1-A4, F. solani exposed to B1, B7, B8 and B9: B1-B3, Alternaria sp. exposed to B1, B7, B8 and B9)

as one of the probable mechanisms of action of these endophytic bacterial strains on the tested fungal pathogens of date palm.

\section{Conclusions}

Obtained results showed that the endophytic P. septica strains obtained from the leaves of date palm cultivar Nighal suppressed the growth of F. solani and Alternaria sp. and caused morphological abnormalities in their mycelia. Further, cell-free culture filtrates of these bacterial strains suppressed the growth of these pathogens and induced electrolyte leakage from the mycelia. To our knowledge, this is the first detailed study on endophytic

Table 3 Leakage of electrolytes from the mycelia of Fusarium solani and Alternaria sp. due to antifungal activity of cell-free culture supernatants of endophytic bacterial isolates

\begin{tabular}{llll}
\hline & Bacterial strains & \multicolumn{2}{l}{ Electrolyte leakage $(\mathbf{m S})$} \\
\cline { 2 - 4 } Fusarium solani & B1 & $\mathbf{0} \mathbf{2}$ & $\mathbf{2 ~ h}$ \\
& B7 & $8.92 \pm 0.0 \mathrm{a}$ & $9.65 \pm 0.01 \mathrm{a}$ \\
& B8 & $8.92 \pm 0.0 \mathrm{a}$ & $9.67 \pm 0.07 \mathrm{a}$ \\
& B9 & $8.92 \pm 0.0 \mathrm{a}$ & $9.47 \pm 0.06 \mathrm{~b}$ \\
& Distilled water control & $0.39 \pm 0.29 \mathrm{~b}$ & $0.55 \pm 0.01 \mathrm{c}$ \\
& B1 & $8.92 \pm 0.0 \mathrm{a}$ & $9.65 \pm 0.06 \mathrm{a}$ \\
& B7 & $8.92 \pm 0.0 \mathrm{a}$ & $9.41 \pm 0.13 \mathrm{~b}$ \\
& B8 & $8.92 \pm 0.0 \mathrm{a}$ & $9.63 \pm 0.04 \mathrm{a}$ \\
& B9 & $8.92 \pm 0.0 \mathrm{a}$ & $9.71 \pm 0.04 \mathrm{a}$ \\
& Distilled water control & $0.39 \pm 0.29 \mathrm{~b}$ & $0.55 \pm 0.01 \mathrm{c}$ \\
\hline
\end{tabular}

bacteria of date palm leaves. Further experiments are needed to evaluate the efficacy of these bacterial strains to control F. solani and Alternaria sp.-induced leaf spot diseases of date palm.

\section{Abbreviations}

NA: Nutrient agar; PDA: Potato dextrose agar; PCR: Polymerase chain reaction; SEM: Scanning electronic microscope; SD: Standard deviation

\section{Acknowledgements}

"Not applicable" in this section.

\section{Authors' contributions}

$\mathrm{HH}$. Main author (PhD student) and contributed in all sections of the manuscript. NS. Contributed in sample collection and methodology section. AA. Supervised and contributed in the part of scanning electronic microscope. SN. Co-supervisor and prepare the phylogenetic tree and helped in all analysis of molecular work. RV Co-supervisor and contributed in all sections of the manuscript. AM. Main supervisor and contributed in all sections of the manuscript. We confirm that the manuscript has been read and approved by all named authors. We confirm that the order of authors listed in the manuscript has been approved by all named authors.

\section{Funding}

All of the sources of funding for the work described in this publication are acknowledged below:

The authors thank Sultan Qaboos University and VALE for supporting the study through the projects SR/AGR/CROP/17/01 and EG/AGR/CROP/12/01,03.

Availability of data and materials

Presented in the main manuscript.

\section{Declarations}

Ethics approval and consent to participate

We work on plant samples, so there is no need for ethical approval.

Consent for publication

"Not applicable" in this section. 


\section{Competing interests}

No competing interest exists. We wish to confirm that there are no known conflicts of interest associated with this publication and there has been no significant financial support for this work that could have influenced its outcome.

Received: 11 December 2020 Accepted: 11 April 2021

Published online: 17 April 2021

\section{References}

Al-Badri BAS, Al-Maawali SS, Al-Balushi ZM, Al-Mahmooli IH, Al-Sadi AM Velazhahan R (2020) Cyanide degradation and antagonistic potential of endophytic Bacillus subtilis strain BEB1 from Bougainvillea spectabilis Willd. Front Life Sci 13:92-98

Al-Hussini HS, Al-Rawahi AY, Al-Marhoon AA, Al-Abri SA, Al-Mahmooli IH, Al-Sadi AM, Velazhahan R (2019) Biological control of damping-off of tomato caused by Pythium aphanidermatum by using native antagonistic rhizobacteria isolated from Omani soil. J Plant Pathol 101(2):315-322. https://doi.org/10.1 007/s42161-018-0184-x

Al-Nadabi H, Maharachchikumbura SS, Al-Gahaffi ZS, Al-Hasani AS, Velazhahan R, Al-Sadi AM (2020) Molecular identification of fungal pathogens associated with leaf spot disease of date palms (Phoenix dactylifera). All Life 13(1):587597. https://doi.org/10.1080/26895293.2020.1835740

Al-Nadabi HH, Maharachchikumbura SSN, Agrama H, Al-Azri M, Nasehi A, Al-Sadi AM (2018) Molecular characterization and pathogenicity of Alternaria species on wheat and date palms in Oman. Eur J Plant Pathol 152(3):577-588. https://doi.org/10.1007/s10658-018-1550-4

Ben Mefteh F, Daoud A, Chenari Bouket A, Thissera B, Kadri Y, Cherif-Silini H, Eshelli M, Alenezi FN, Vallat A, Oszako T, Kadri A (2018) Date palm trees rootderived endophytes as fungal cell factories for diverse bioactive metabolites. Int J Mol Sci 19(7):1986. https://doi.org/10.3390/ijms19071986

Bryk H, Dyki B, Sobiczewski P (1998) Antagonictic effect of Erwinia herbicola on in vitro spore germination and germ tube elongation of Botrytis cinerea and Penicillium expansum. Biol Control 43:97-106

Chao CT, Krueger RR (2007) The date palm (Phoenix dactylifera L.): overview of biology, uses, and cultivation. HortScience 42(5):1077-1082. https://doi.org/1 0.21273/HORTSCl.42.5.1077

Chen C, Xin K, Liu H, Cheng J, Shen X, Wang Y, Zhang L (2017) Pantoea alhagi, a novel endophytic bacterium with ability to improve growth and drought tolerance in wheat. Sci Rep 7:1-14

Compant S, Clément C, Sessitsch A (2010) Plant growth-promoting bacteria in the rhizo-and endosphere of plants: their role, colonization, mechanisms involved and prospects for utilization. Soil Biol Biochem 42(5):669-678. https://doi.org/10.1016/j.soilbio.2009.11.024

El Hassni M, El Hadrami A, Daayf F, Chérif M, Barka EA, El Hadrami I (2007) Biological control of bayoud disease in date palm: Selection of microorganisms inhibiting the causal agent and inducing defense reactions. Environ Exp Bot 59(2):224234. https://doi.org/10.1016/j.envexpbot.2005.12.008

El-Deeb HM, Arab YA (2013) Acremonium as an endophytic bioagent against date palm Fusarium wilt. Arch Phytopathol Plant Protect 46(10):1214-1221. https:// doi.org/10.1080/03235408.2013.763615

El-Deeb HM, Lashin SM, Arab YA (2007) Distribution and pathogenesis of date palm fungi in Egypt. Acta Hortic 736:421-429

FAO (2019) FAOSTAT. www.fao.org.

Frank AC, Saldierna Guzmán JP, Shay JE (2017) Transmission of bacterial endophytes. Microorganisms 5(4):70. https://doi.org/10.3390/microorga nisms5040070

Garg H, Li H, Sivasithamparam K, Kuo J, Barbetti MJ (2010) The infection processes of Sclerotinia sclerotiorum in cotyledon tissue of a resistant and a susceptible genotype of Brassica napus. Ann Bot 106(6):897-908. https://doi. org/10.1093/aob/mcq196

Halo BA, Al-Yahyai RA, Al-Sadi AM (2018) Aspergillus terreus inhibits growth and induces morphological abnormalities in Pythium aphanidermatum and suppresses Pythium-induced damping-off of cucumber. Front Microbiol 9:95. https://doi.org/10.3389/fmicb.2018.00095

Han-Jen RE, Wai-Fong Y, Kok-Gan C (2013) Pandoraea sp. RB-44, a novel quorum sensing soil bacterium. Sensors 13(10):14121-14132. https//doi.org/10.3390/s131014121

Heydari A, Pessarakli M (2010) A review on biological control of fungal plant pathogens using microbial antagonists. J Biol Sci 10(4):273-290. https://doi. org/10.3923/jbs.2010.273.290
Huffaker CB, Messenger PS (eds) (1976) Theory and practice of biological control. Academic Press, New York, p 788

Ishimaru CA, Klos EJ, Brubaker RR (1988) Multiple antibiotic production by Erwinia herbicola. Phytopathology 78(6):746-750. https://doi.org/10.1094/Phyto-78-746

Jiang L, Jeong JC, Lee JS, Park JM, Yang JW, Lee MH, Choi SH, Kim CY, Kim DH, Kim SW, Lee J (2019) Potential of Pantoea dispersa as an effective biocontrol agent for black rot in sweet potato. Sci Rep 9(1):16354. https://doi.org/10.103 8/541598-019-52804-3

Kempf HJ, Wolf G (1989) Erwinia herbicola as a biocontrol agent of Fusarium culmorum and Puccinia recondita f.sp. tritici on wheat. Phytopathology 79(9): 990-994. https://doi.org/10.1094/Phyto-79-990

Kotze C, Van Niekerk J, Mostert L, Halleen F, Fourie P (2011) Evaluation of biocontrol agents for grapevine pruning wound protection against trunk pathogen infection. Phytopathol Mediterr 50:S247-S263

Kumar A, Shukla R, Singh P, Prasad CS, Dubey NK (2008) Assessment of Thymus vulgaris $L$. essential oil as a safe botanical preservative against post-harvest fungal infestation of food commodities. Innov Food Sci Emerg Technol 9(4): 575-580. https://doi.org/10.1016/j.fset.2007.12.005

Manhas RK, Kaur T (2016) Biocontrol potential of Streptomyces hydrogenans strain DH16 toward Alternaria brassicicola to control damping off and black leaf spot of Raphanus sativus. Front Plant Sci 7:1869

Mohamad OAA, Li L, Ma J-B, Hatab S, Xu L, Guo J-W, Rasulov BA, Liu Y-H, Hedlund BP, Li WJ (2018) Evaluation of the antimicrobial activity of endophytic bacterial populations from Chinese traditional medicinal plant Licorice and characterization of the bioactive secondary metabolites produced by Bacillus atrophaeus against Verticillium dahliae. Front Microbiol 9:924. https://doi.org/10.3389/fmicb.2018.00924

Pal KK, Gardener BM (2006) Biological control of plant pathogens. Plant Health Instr. https://doi.org/10.1094/PHI-A-2006-1117-02

Pandey DK, Chandra H, Tripathi NN (1982) Volatile fungitoxic activity of some higher plants with special reference to that of Callistemon lanceolatus DC. J Phytopathol 105(2):175-182. https://doi.org/10.1111/j.1439-0434.1982.tb00675.x

Plaza P, Usall J, Smilanick JL, Lamarca N (2004) Combining Pantoea agglomerans (CPA-2) and curing treatments to control established infections of Penicillium digitatum on lemons. J Food Prot 67(4):781-786. https://doi.org/10.4315/03 62-028X-67.4.781

Prapagdee B, Kuekulvong C, Mongkolsuk S (2008) Antifungal potential of extracellular metabolites produced by Streptomyces hygroscopicus against phytopathogenic fungi. Int J Biol Sci 4(5):330-337. https://doi.org/10.7150/ ijbs.4.330

Rosenblueth M, Martínez-Romero E (2006) Bacterial endophytes and their interactions with hosts. Mol Plant-Microbe Interact 19(8):827-837. https://doi. org/10.1094/MPMI-19-0827

Saeed EE, Sham A, Salmin Z, Abdelmowla Y, Iratni R, El-Tarabily K, AbuQamar S (2017) Streptomyces globosus UAE1, a potential effective biocontrol agent for black scorch disease in date palm plantations. Front Microbiol 8:1455. https:/ doi.org/10.3389/fmicb.2017.01455

Siala R, Chobba IB, Vallaeys T, Triki MA, Jrad M, Cheffi M, Ayedi I, Elleuch A, Nemsi A, Cerqueira F, Gdoura R (2016) Analysis of the cultivable endophytic bacterial diversity in the date palm (Phoenix dactylifera $\mathrm{L}$.) and evaluation of its antagonistic potential against pathogenic Fusarium species that cause date palm bayoud disease. J Appl Environ Microbiol 4:93-104

Silvestro D, Michalak I (2012) raxmlGUI: a graphical front-end for RAxML. Org Divers Evol 12(4):335-337. https://doi.org/10.1007/s13127-011-0056-0

Vasebi Y, Alizadeh A, Safaie N (2015) Pantoea agglomerans ENA1 as a biocontrol agent of Macrophomia phaseolina and growth enhancer of soybean. J Crop Prot 4:43-57

Yaish MW, Al-Harrasi I, Alansari AS, Al-Yahyai R, Glick BR (2016) The use of high throughput DNA sequence analysis to assess the endophytic microbiome of date palm roots grown under different levels of salt stress. Int Microbiol 19(3):143-155. https://doi.org/10.2436/20.1501.01.272

Yaish MW, Antony I, Bernard RG (2015) Isolation and characterization of endophytic plant growth promoting bacteria from date palm tree (Phoenix dactylifera L.) and their potential role in salinity tolerance. Antonie Van Leeuwenhoek 107(6):1519-1532. https://doi.org/10.1007/s10482-015-0445-z

\section{Publisher's Note}

Springer Nature remains neutral with regard to jurisdictional claims in published maps and institutional affiliations. 